DOI:

\title{
BUSINESS RUSSIAN AT A POLISH HIGHER EDUCATION INSTITUTION - SELECTED ISSUES CONCERNING TEACHING BUSINESS LANGUAGE TO THE STUDENTS OF RUSSIAN PHILOLOGY
}

\author{
Malgorzata Widel-Ignaszczak \\ Ph.D. of Philology, assistant professor \\ John Paul II Catholic University of Lublin \\ (Lublin, Poland) \\ e-mail: goswid@gmail.com
}

\begin{abstract}
The paper aims to present the issue of teaching Business Russian at Polish higher education institutions. Teaching languages for specific purposes to university students of foreign philologies has been different for years from teaching them in language schools or within practical language courses in economics departments. This entails a wide range of problems both at an institutional level, with regard to adopting curricula, teaching materials, organizing practical placements, and at a student level, with regard to working with him on developing professional competence or increasing motivation. The paper also discusses the correlation between the academic teaching process and the demands of the labour market in Poland.
\end{abstract}

Keywords: academic teaching in Poland, Business Russian, professional competence, increasing motivation, language for special purposes, professional communication, socio-cultural competence.

\section{РУССКИЙ ЯЗЫК ДЕЛОВОГО ОБЩЕНИЯ В ПОЛЬСКОМ ВУЗЕ - ИЗБРАННЫЕ ВОПРОСЫ ОБУЧЕНИЯ ФИЛОЛОГОВ-РУСИСТОВ ЯЗЫКУ БИЗНЕСА}

\author{
Малгожата Видел-Игнашчак \\ Кандидат филологических наук, адъюнкт \\ Люблинский католический университетет Иоанна Павла II \\ (Люблин, Польша) \\ e-mail: goswid@gmail.com
}

\begin{abstract}
Аннотация. Целью статьи является представить специфику преподавания русского языка в сфере бизнеса в университетах Польши. Академическая дидактика в области специальных языков при филологических направлениях годами отличалась от преподавания этих языков в языковых школах или в рамках языковых курсов на экономических факультетах. Это подразумевает широкий спектр проблем как на институциональном уровне, в том числе в отношении выбора учебных программ, дидактических материалов, организации обучения, так и на уровне работы со студентом-филологом в области развития его профессиональной компетенции или стимулирования мотивации. В статье также подчеркивается взаимозависимость между процессом университетского образования и требованиями рынка труда в Польше.
\end{abstract}


Ключевые слова: университетская дидактика в Польше, русский язык в бизнесе, профессиональная компетенция, мотивация, язык для специальных целей, социокультурная компетенция.

\section{ВВЕДЕНИЕ}

Приобретение определенных профессиональных компетенций является основным требованием современного рынка труда, удовлетворение потребности которого, в свою очередь, стало вызовом для академического образования. Профессионализация учебного процесса определяет потребность создавать новые учебные программы в рамках русской филологии в университетах Польши. Характерной чертой польского образовательного рынка является универсальный доступ к высшему образованию, которое, особенно в условиях демографического падения, призвано повысить привлекательность образовательного предложения (cp. Mocarz-Kleindienst 2015, 90). В прошлом традиционное филологическое образование русистов в Польше, исключало прикладную направленность обучения. Сегодня образовательные программы русского языка на филологическом направлении, все реже охватывают только обучение языку и литературе, а дополнением образования служат специальности: переводческая и/или русский язык в бизнесе, в туризме, на таможне и т. д.

Геополитическое положение Польши обусловливает взаимные контакты с Россией, включая сферу экономики, поэтому уже почти двадцать лет в Польше наблюдается оживление в исследованиях и практических разработках в области дидактики специальных языков, в том числе, в области русского языка делового общения или русского языка бизнеса (Dabrovski 2018, 93; Krenska 2009, 146).

\section{РОЛЬ МОТИВАЦИИ ВЗРОСЛЫХ УЧАЩИХСЯ В КОНТЕКСТЕ УСЛОВИЙ РЫНКА ТРУДА- ИЗБРАННЫЕ ДЕТЕРМИНАНТЫ}

Внутренняя мотивация взрослых учащихся очень высокая. Обучение специалиста в области русского языка и стремление развивать его профессиональную и языковую компетенцию в настоящее время сосредоточены на потребностях учащегося, что, в свою очередь, выражается в требованиях участников языкового курса: филологов, будущих сотрудников различных профессиональных групп. Эти потребности отражаются в целях и содержании обучения, а также формах упражнений. Они должны осуществляться в двух направлениях: это - обучение в научных и теоретических целях, а также обучение в профессиональных целях в связи с вертикальным разделением специальных языков. Вышеуказанные направления осуществляется в соответствии со степенью абстракции языка и среды общения участников, и, прежде всего, с уровнем их профессиональной компетенции, то есть овладением знаниями, основанными на профессиональном, специальном содержании и навыках данного человека (Cholewa 2013, 76). С целью подготовить учащихся к работе в определенных профессиональных ситуациях, предлагается, чтобы учебный процесс включал в себя симуляции, ролевые игры, а также подготовку проектов, тематические исследования и устные презентации. Это ориентированный на учащихся подход, позволяющий им ознакомиться с соответствующими стратегиями обучения, которые поддерживают их на пути к автономии. Учащиеся знают, как учиться, развивают мотивацию к обучению, сами несут ответственность за свое обучение (ср. Zientala 2004, 111). Важнейшие факторы 
автономизации в обучении русскому языку в бизнесе - это между прочим: 1) возможность приспособить темп работы и программы обучения для нужд студентов, 2) максимальная активизация учащегося, 3) развитие у студента умения самообразования, 4) внедрение элементов аутентизма общения на русском языке (cp. Zarska 2005, 61).

Целью обучения на базовом уровне является прежде всего приобретение студентами основных коммуникативных навыков в профессиональной сфере, охватывающей темы, связанные с предприятием. Зато на уровне, рассматриваемого в настоящей статье, высшего образования, при владении русским языком на уровне, как минимум, Б2 - С1, желаемые результаты достигаются, прежде всего, посредством аудиторной работы с профессиональными и аутентичными текстами, высказываниями, видео- и аудиоматериалами. Студенты как воспринимают тексты, так и сами их производят.

Критериями подбора специального текста являются функциональная обоснованность и насыщенность соответствующими терминами, которая отличает его от неспециального и является основным показателем его принадлежности к данной профессиональной сфере (ср. Grucza, 2006, 39). Тексты, используемые при обучении русскому языку в бизнесе, должны быть четко социокультурно, ситуативно и функционально обусловленными. Таким образом, языковая деятельность учащихся фокусируется на типах текстов, используемых для устного и письменного общения. Например: на уровне высшего филологического образования можно упомянуть жанры, представленные в форме монолога (например, выступление на конференции, брифинге, на радио или телевидении, деловая презентация) и диалога или полилога (например, телефонная и личная деловая беседа, видеоконференция, обсуждения на совещаниях, переговоры). Письменные типы текстов включают коммерческую корреспонденцию, официальные документы, банковские и страховые документы, транспортную и экспедиторскую документацию, документы, связанные с таможенным оформлением, ряд документов, представляющих собой подготовку к заключению различных типов коммерческих контрактов, а также тексты самих контрактов. Важной сферой являются аутентичные тексты законодательных и нормативных актов, регулирующих деятельность международных компаний или организаций.

В свою очередь, чем выше уровень коммуникативной компетенции учащихся, тем чаще в учебный процесс в области иностранного языка включаются элементы дидактики в научных и теоретических целях. Профессиональное и научно-теоретическое содержание составляют единое, неотделимое целое. Они не являются взаимоисключающими, потому что все языковые действия идут в одном направлении: к достижению ситуации, когда развитие языковой компетенции является одновременным развитием профессиональной компетенции. В сегодняшнем университете цель обучения заключается не только в том, чтобы достичь высокого уровня владения языком, как это было в предыдущие десятилетия, а также в том, чтобы развивать профессиональную коммуникативную компетенцию в сочетании с лингвистическим и специализированным содержанием, включая межкультурный контент.

Многие студенты ценят возможность прохождения стажировки во время обучения, которая является неотъемлемой частью почти всех программ специализаций. Стажировка проходит в компаниях и других учреждениях, где учащиеся применяют приобретенные знания и навыки на практике. Возможность адекватного участия в польско-российском деловом общении является необходимым условием эффективного присутствия филолога на рынке труда. 


\section{ОБУЧЕНИЕ ОБЩЕМУ ЯЗЫКУ, ЯЗЫКУ ДЛЯ СПЕЦИАЛЬНЫХ ЦЕЛЕЙ ИЛИ ОБУЧЕНИЕ СПЕЦИАЛЬНЫМ ЗНАНИЯМ?}

Студент, изучающий не только язык, но и основные составляющие культуры, национальный характер, должен знать также культурные коды делового партнера, принципы коммуникационного этикета и названия реалий современного общества - здесь в помощь приходят навыки и знания, освоенные в рамках элементов традиционного филологического образования.

Изучая русский деловой язык, студенты целенаправленные на достижение социокультурной компетенции. Приобретают знания об экономических системах в странах бывшего Советского Союза и Евросоюза, о социальном поведении и важных аспектах национальной культуры россиян, их менталитете и стереотипах. Отсутствие этих знаний создает барьеры эффективного общения. Д. Н. Володина справедливо заключает: «корректное вербальное и невербальное поведение в типичных ситуациях делового общения базируется на понимании основных законов делового дискурса, знании его лингвистических и культурологических особенностей» (Volodina, 2011, 83). Развитие профессиональной компетенции студентов в области русского языка в бизнесе предполагает активацию социолингвистических знаний, то есть понимания социального контекста, в котором происходит общение, что приводит к эффективному использованию языка в различных ситуациях.

Такое положение вещей обусловлено прежде всего тесной связью теории и практики. (Cwiklińska and Shadyko 2005, 81-88). Трудно представить достижение целей коммуникации, возникающих во время трудовой деятельности учащихся, например, определения (или перевода) условий договора без необходимых знаний о правовой системе в России, правилах подготовки таких документов, знаний об этикете общения во время деловых встреч, знаний о правилах ведения переговоров с российскими партнерами и т.д. В программах специализаций в польских вузах, как правило, имеется блок теоретических предметов, позволяющих студентам ознакомиться на основном уровне с историей, реалиями и экономикой страны, изучаемого языка.

Следовательно, эффективное общение является целью и средством, поэтому наряду с целенаправленной практической деятельностью, сегодня довольно популярной тенденцией в преподавании языка является предметно-языковое интегрированное обучение, то есть обучение языку через контент (CLIL - Content and Language Integrated Learning), которая включает интеграцию содержания с целями обучения языку. Наиболее важной проблемой в концепции обучения через контент является использование второго языка для получения знаний и одновременное развитие языковых навыков. Поэтому обучение русскому языку в бизнесе должно быть в итоге направлено на то, чтобы дать возможность учащимся не только приобрести лингвистические и коммуникативные навыки, но и иметь возможность компетентно общаться на русском языке в профессиональной среде. Учитель вынужден обеспечить дидактический процесс широким запасом аутентичных материалов (текстов, видео- и аудиоматериалов), чтобы создать возможность имитации естественного общения. 


\section{ФОРМИРОВАНИЕ СОЦИОКУЛЬТУРНОЙ КОМПЕТЕНЦИИ У ПОЛЬСКИХ СТУ ДЕНТОВ-РУСИСТОВ}

Овладение языком бизнеса означает не только приобретение, большего или меньшего в зависимости от целей обучения, лексического запаса (в основном экономической терминологии). Однако только знание языка и культуры в сочетании с профессиональными знаниями позволит выпускникам вузов участвовать в деловом общении. Основной предпосылкой и главной целью построения языковых курсов делового языка является эффективность. Усилия преподавателей в этой области позволяют уточнить не только лингвистическое, но и социокультурное содержание обучения, а также подбор адекватных и разнообразных учебных материалов (Widel-Ignaszczak 2015, 172).

Социокультурный контент обучения должен предоставляться на каждом этапе обучения русскому деловому языку, поскольку «в основе языковых структур лежат структуры социокультурные» (Ter-Minasova 2008, 29). Однако их активизация в дидактическом процессе происходит по-разному на разных этапах обучения. Возможность адекватного участия в польско-российском деловом общении является необходимым условием эффективной работы студента-филолога в будущем. Учащийся, изучающий не только язык, но и основные составляющие культуры, национальный характер, должен знать культурные коды делового партнера (например, восприятие времени, субординация, система ценностей, невербальная коммуникация и др.), а также принципы речевого этикета и названия реалий современного общества. Социокультурная компетенция, таким образом, позволяет студенту варьировать речевое поведение в зависимости от сферы и ситуации общения.

Анализ учебных программ русской филологии в Польше позволяет констатировать их межкультурную перспективу, которую Г. Зентала назвал «миром российского бизнеса». Этот подход подразумевает, что учащийся ощущает себя участником сферы бизнеса. «Деловой мир» - это очень емкое понятие, наполненное социокультурной информацией. Наличие специальных и социокультурных знаний является обязательным условием для правильной подготовки квалифицированного специалиста по русскому языку в бизнесе (Zentala 2012, 58). С. Магала утверждает, что: ученые, консультанты, менеджеры начинают открывать и использовать вербальные и невербальные знания, ритуалы, символы и модели поведения. Это разнообразие все чаще рассматривается как возможность для творческого развития (Magala 2011, 9-10). Студенты русской филологии специальности «Русский язык в бизнесе» на занятиях в группах, а также индивидуально в рамках порученных проектов, собственнолично «открывают» фиктивные фирмы, представляют их на организованных в рамках группы ярмарках, ведут официальную переписку и переговоры, налаживают сотрудничество с партнерами, дают/берут интервью. Таким образом, в симуляциях естественных ситуаций употребляют речевой этикет делового общения.

\section{ЗАКЛЮЧЕНИЕ}

Подытоживая, стоит подчеркнуть, что подготовка специалиста по иностранным языкам включает в себя сочетание 1) языковых, 2) профессиональных и 3) социокультурных знаний и их практическое применение. Цели и содержание обучения ориентированы на 
потребности взрослых, целеустремленных учащихся - то есть развитие профессиональных навыков общения на русском языке.

В статье рассмотрено детерминанты эффективности обучения русскому языку делового общения на уровне высшего филологического образования, которую обусловливает учёт специального и социокультурного содержания обучения, а также использование соответственных и разнообразных стратегий, техник и обучающих материалов.

\section{LIST OF REFERENCES}

Cwiklinska J., Shadyko, S. (2005). Obszary wiedzy specjalistycznej w wybranych wariantach języka Business Communications [Areas of specialist knowledge in selected variants of the Business Communications language]. Języki specjalistyczne, 5, 81-88.

Cholewa J. (2013). Nauczanie języków specjalistycznych wczoraj i dziś [Specialist language teaching yesterday and today]. Języki obce w szkole, 4, 75-80.

Dabrowski T. (2018). Istoricheskiy ocherk prepodavaniya russkogo yazyka v Pol'she [Historical essay on teaching Russian as a foreign language in Poland]. Russkiy yazyk za rubezhom, 4, 8694.

Grucza S. (2006). Idiolekt specjalistyczny - idiokultura specjalistyczna - interkulturowość specjalistyczna [Specialist idiolect - specialist idioculture - specialist interculturality]. Języki specjalistyczne, 6, 30-49.

Krenska N. (2009). Russkiy yazyk biznesa v Pol'she - yego osnovnye problemy [Russian language of business in Poland - main problems]. Komunikacja specjalistyczna, 2, 146-155.

Magala S. J. (2011). Kompetencje międzykulturowe [Intercultural competences]. trans. J. F Dąbrowski. Warszawa: Oficyna a Wolters Kluwer business.

Mocarz-Kleindienst M. (2015). Języki specjalistyczne w programach nauczania na kierunkach slawistycznych [Specialist languages in the curricula of degree programmes in Slavonic Studies]. In. M. Sowa et. al. (ed.), Nauczanie języków obcych na potrzeby rynku pracy, Lublin: Wydawnictwo KUL, 90-97.

Pluzycka M. (2008). Obucheniye vospriyatiyu teksta v didaktike spetsial'nogo yazyka (na materiale tekstov preddogovornoy perepiski [Teaching text perception in the didactics of a special language (based on texts of pre-contractual correspondence]. Linguodidactica, XII, 123-134.

Ter-Minasova S. G. (2008). YAzyk i mezhkul'turnaya kommunikatsiya [Language and intercultural communication], Moskva: Slovo.

Widel-Ignaszczak M. (2015). Obszary wiedzy specjalistycznej i socjokulturowej w rosyjskiej komunikacji biznesowej [Specialist and socio-cultural areas of knowledge in teaching Russian business communication]. Roczniki Humanistyczne, 10, LXIII, 163-172.

Volodina D.N. (2011). Formirovaniye sotsiokul'turnoy kompetentsii na urokakh russkogo yazyka kak inostrannogo (sfera delovogo obshcheniya) [The formation of sociocultural competence in the lessons of the Russian language as a foreign language (the sphere of business communication)]. Molodoy uchenyy, 7/2, 83-86.

Zarska A. (2005). Avtonomizatsiya v obuchenii spetsyazykam [Autonization in teaching special languages]. In. A. Palinski, G. Zientala (ed.), Rosyjski język biznesu w wyższej szkole, Rzeszów: Wydawnictwo Uniwersytetu Rzeszowskiego, 59-63. 
Zietala G. (2000). Nauczanie rosyjskiego języka biznesu na studiach rusycystycznych [Teaching Russian business language at Russian studies]. Rzeszów: Wydawnictwo Uniwersytetu Rzeszowskiego.

Zientala G. (2012). Mir russkogo biznesa v obuchenii spetsialistov po delovomu russkomu yazyku [The world of Russian business in training specialists in business Russian]. Szczecin: Wydawnictwo Volumina.pl.

\section{For citation:}

Widel-Ignaszczak, M. (2020). Business Russian at a Polish Higher Education Institution - selected issues concerning teaching business language to the students of Russian Philology. International Scientific-Pedagogical Organization of Philologists “WEST-EAST " (ISPOP). Scientific Journal WEST-EAST. Vol 3 N1 (March, 2020). pp. 11-16. doi:

\section{Для цитирования:}

Видел-Игнашчак, М. (2020). Русский язык делового общения в польском вузе - избранные вопросы обучения филологов-русистов языку бизнеса // International Scientific-Pedagogical Organization of Philologists “WEST-EAST” (ISPOP). Scientific Journal WEST-EAST. Vol 3N1 (March, 2020). C. 11-16. doi:

Information about the author: Malgorzata Widel-Ignaszczak - Ph.D. of Philology, assistant professor Institute of Slavic Philology, Department of Translation Studies and Slavic Languages of John Paul II Catholic University of Lublin (Poland).

e-mail: goswid@gmail.com

Сведения об авторе: Малгожата Видел-Игнашчак - кандидат филологических наук, адъюнкт, Институт славянской филологии, Кафедра переводоведения и славянских языков.Люблинского католического университета Иоанна Павла II, (Польша.)

e-mail: goswid@gmail.com

Manuscript received: 12/01/2019

Accepted for publication: $01 / 14 / 2020$

Рукопись получена: 12/01/2019

Принята к печати: 01/14/2020 